\title{
New Chikyu Shallow Core Program (SCORE): exploring mass transport deposits and the subseafloor biosphere off Cape Erimo, northern Japan
}

\author{
Yusuke Kubo $^{1, \mathrm{a}}$, Fumio Inagaki ${ }^{2, \mathrm{~b}}$, Satoshi Tonai ${ }^{3}$, Go-Ichiro Uramoto $^{4}$, Osamu Takano ${ }^{5}$, \\ Yasuhiro Yamada ${ }^{2,3,6, b}$, and the Expedition 910 Shipboard Scientific Party ${ }^{+}$ \\ ${ }^{1}$ Center for Deep Earth Exploration, Japan Agency for Marine-Earth Science and Technology, \\ Showa-machi 3173-25, Kanazawa-ku, Yokohama 236-0001, Japan \\ ${ }^{2}$ Research and Development Center for Ocean Drilling Science, Japan Agency for Marine-Earth Science and \\ Technology, Showa-machi 3173-25, Kanazawa-ku, Yokohama 236-0001, Japan \\ ${ }^{3}$ Faculty of Science and Technology, Kochi University, Akebono-cho 5-1, Kochi 780-8520, Japan \\ ${ }^{4}$ Center for Advanced Marine Core Research, Kochi University, Monobe B200, \\ Nankoku, Kochi 783-8502, Japan \\ ${ }^{5}$ JAPEX Research Center, Technical Division, Japan Petroleum Exploration (JAPEX), \\ Hamada 1-2-1, Mihama-ku, Chiba 261-0025, Japan \\ ${ }^{6}$ Department of Earth Sciences, Royal Holloway University of London, Egham, TW20 0EX, UK \\ ${ }^{a}$ present address: Kochi Institute for Core Sample Research, Japan Agency for Marine-Earth Science and \\ Technology, Monobe B200, Nankoku, Kochi 782-8502, Japan \\ ${ }^{b}$ present address: Mantle Drilling Promotion Office (MDP), Institute for Marine-Earth Exploration and \\ Engineering (MarE3), Japan Agency for Marine-Earth Science and Technology (JAMSTEC), \\ Showa-machi 3173-25, Kanazawa-ku, Yokohama 236-0001, Japan

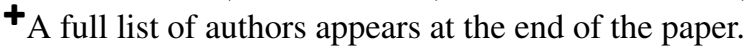 \\ Correspondence: Satoshi Tonai (s-tonai@kochi-u.ac.jp)
}

Received: 16 August 2019 - Revised: 9 January 2020 - Accepted: 10 January 2020 - Published: 27 May 2020

\begin{abstract}
The Chikyu Shallow Core Program (SCORE) has been started to provide more opportunities for the scientific ocean drilling of shallow boreholes (up to $100 \mathrm{~m}$ ) during a short-term expedition. The proposal flow is a simplified version of that of the International Ocean Discovery Program (IODP). Although there are several limitations for a SCORE project, the opportunity to retrieve $100 \mathrm{~m}$ of continuous core samples will be of great interest for the scientific ocean drilling community in multiple disciplines. The first expedition of the SCORE program was implemented off Cape Erimo, Hokkaido, northern Japan. The target of the drilling was to investigate the impact of submarine mass transport on the subseafloor sedimentary biosphere. In the preliminary observation of the core samples, including X-ray computed tomography (CT) scan image analysis, chaotic and inclined beds were found and interpreted as mass transport deposit (MTD) units.
\end{abstract}




\section{Introduction}

The drilling vessel Chikyu has implemented more than 20 scientific ocean drilling expeditions for the IODP (Integrated Ocean Drilling Program and International Ocean Discovery Program) since 2007. Because the Chikyu is the only riser drilling platform for scientific ocean drilling, previous IODP expeditions have mainly focused on very deep subseafloor targets such as seismogenic zones in accretionary prisms and the deep biosphere within coal and shale beds. However, opportunities for utilizing the Chikyu might have been limited for the exploration of relatively shallow horizons, because the riser drilling expeditions often tend to be long, expensive, and complicated, taking years from the initial proposal submission to the implementation. To maximize the use of the Chikyu for the broader science and educational community, a new framework for scientific ocean drilling, the Chikyu Shallow Core Program (SCORE), has been initiated under a collaboration between the Japan Drilling Earth Science Consortium (J-DESC) and Japan Agency for Marine-Earth Science and Technology (JAMSTEC). SCORE is designed to implement short-term expeditions in a relatively simple process using hydraulic piston coring. It would add extra value to the Chikyu if more opportunities were made available for the ocean drilling community to take part in Chikyu expeditions without the time, effort, and cost necessary for major longterm expeditions. In this article, the concept of SCORE and preliminary results from its first expedition (910) off Cape Erimo in September 2017 are introduced.

\subsection{SCORE}

SCORE is a new programme of J-DESC to utilize the Chikyu for drilling shallow boreholes during a short-term expedition. Any scientist from a member institution of J-DESC can submit a drilling proposal with a format similar in length to an IODP pre-proposal. Although the lead proponent must be associated with a member institution of J-DESC, any scientist may be a co-proponent and is eligible to participate in an expedition. The proposal flow of SCORE is a simplified version of that of the IODP (the format is available at the J-DESC website https://www.j-desc.org/score/, last access: 13 February 2020). The IODP section in J-DESC reviews the proposal and forwards it to the Institute for Marine-Earth Exploration and Engineering (MarE3) in JAMSTEC with recommendations, if the proposal is scientifically mature enough for implementation in the future. MarE3 determines whether the proposal fits within operational constraints (budget, schedule, logistics, etc.).

Due to the short timeframe of the drilling, there are several limitations for a SCORE project. First, drilling operations are limited to hydraulic piston coring of sediment down to $\sim 100 \mathrm{~m}$ below seafloor (m b.s.f.). Second, proposed drilling sites located on, or nearby, the planned ship track of the Chikyu (see the J-DESC website) are preferred. Third, ship- board flow of analyses is limited as compared to the standard measurement procedures on an IODP expedition due to the short duration of the expedition and a reduced number of shipboard technical staff. Typically, non-destructive analysis of whole-round cores and image scanning after core splitting are conducted onboard. In addition to the limitations in such operational and analytical conditions, proponents should be aware that J-DESC provides no financial support for expedition participants (as of today). While MarE3 implements drilling operations and provides support for core curation and minimal data collection, proponents and team members should prepare necessary costs for travel and accommodations, sample shipping, onboard and post-expedition research activities, etc. Nevertheless, in addition to supplementing full IODP expeditions, the opportunity to retrieve $100 \mathrm{~m}$ of continuous core samples will be of great interest for the scientific ocean drilling community in multiple disciplines.

\subsection{Expedition 910: drilling west off Cape Erimo}

The first SCORE expedition with the Chikyu was conducted from 19 to 23 September 2017, based on the proposal "Deep Learning of Deep Life: Exploring impact of submarine landslides on the deep biosphere-evolution off Cape Erimo" proposed by the lead proponent Fumio Inagaki of JAMSTEC. Since the Ocean Drilling Program (ODP) Leg 201, numerous microbiological and biogeochemical studies have demonstrated that Earth's biosphere extends far below its surface, at least down to $\sim 2.5 \mathrm{~km}$ beneath the ocean floor on the continental margin (Inagaki et al., 2015). Based on the accumulated evidence of microbial biomass in subseafloor sediments in various oceanographic and geological settings, a recent numerical model study estimated that a total of $10^{29}$ microbial cells are present in the global subseafloor biosphere, accounting for $4 \mathrm{Pg}$ of biomass carbon on Earth (Kallmeyer et al., 2012). Previous scientific ocean drilling also demonstrated that activity of aerobic and anaerobic subseafloor microbial communities is generally extraordinarily low; i.e. mean organic-fuelled respiration rates range from $2.8 \times 10^{-18}$ moles e- per cell per year in anaerobic sediments in the eastern equatorial Pacific to $1.1 \times 10^{-14}$ moles e- per cell per year in aerobic SPG sediments (D'Hondt et al., 2004, 2015; Hoehler and Jørgensen, 2013). In addition, these sedimentary communities in both aerobic and anaerobic subseafloor habitats consist mainly of species evolutionarily very distinct from known microbes in Earth's surface biosphere (e.g. Inagaki et al., 2003, 2006). Previous metagenomic and metatranscriptomic studies have found that those physiology and metabolic functions are also very distinct and adapted to the sedimentary biosphere where the energy flux is extremely low (Biddle et al., 2006; Orsi et al., 2013; Tully and Heidelberg, 2016; Valentine, 2007). To date, however, little is known about how such deeply buried "slow life" responds to changes in the surrounding environment. 
In SCORE Expedition 910 off Cape Erimo, we targeted the community response and succession of the sedimentary biosphere associated with earthquake- and/or climate change-triggered mass transport deposits (MTDs) in that area. During the past decade, our knowledge of submarine mass movements including submarine landslides has significantly expanded worldwide, with realization of their destructive impact and tsunami-generation potential (e.g. Yamada et al., 2012). However, it still remains unknown how environmental changes caused by submarine landslides have impacted the modern subseafloor biosphere, how the deeply buried microbial communities have responded to the physical and chemical changes in their stable habitat, and what the succession and resilience of the microbial ecosystem and potential roles are in biogeochemical element cycling. Establishing high-resolution depth-age profiles of various environmental factors in this site is also useful for considering the occurrence mechanism of the MTDs. These scientific objectives are highly relevant to Biosphere Frontiers: Challenge 7 "How sensitive are ecosystems and biodiversity to environmental change?" and Earth in Motion: Challenge 12 "What mechanisms control the occurrence of destructive earthquakes, landslides, and tsunami?" in IODP Science Plan 2013-2023.

\section{Geological background}

The drilling site is located in the Hidaka Trough, which corresponds to an arc-arc junction between the north-eastern Japan arc and Kuril arc in the southern part of Hokkaido and extends southward to offshore of the Shimokita Peninsula (Fig. 1). The Hidaka Trough originated from a forearc basin that developed along the Pacific Plate subduction zone $\left(\sim 8 \mathrm{~cm} \mathrm{yr}^{-1}\right.$, west-northwest plate motion vector; Seno et al., 1996) and later converted to a foreland basin adjacent to the Hidaka Block collision zone due to the westward migration of the Kuril forearc sliver (Kimura and Kusunoki, 1997; Takano 2017). A large-scale fore-deep subsidence and a tremendous amount of clastic inflow that derived from the uplifted Hidaka Mountains resulted in the thick sedimentary piles of the Neogene foreland basin succession in the Hidaka Trough (Itoh and Tsuru, 2005; Noda et al., 2013). The $5000 \mathrm{~m}$ thick foreland basin-filling succession comprises submarine-fan turbidites, MTDs, siliceous shale and hemipelagic mudstones, depending on the background tectonic conditions at the depositional time and the insidebasin locations (JOGMEC, 2013).

Multiple seismic surveys have been conducted in the Hidaka Trough (JOGMEC, 2013, 2014), providing seismic stratigraphic and structural information on both the deeper and shallower parts of the basin-filling succession. Some seismic sections indicate that the shallower part below the seafloor is dominated by interbedded MTDs and hemipelagic shales. The 3-D topographic maps of the seafloor clearly in-

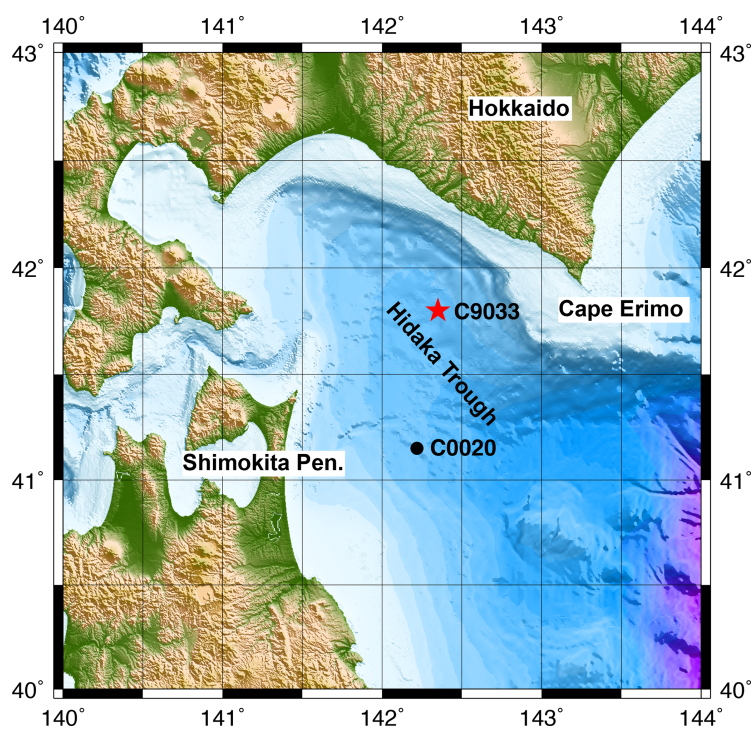

Figure 1. Site C9033 is located west off Cape Erimo, Hokkaido, northern Japan. The site is located $70 \mathrm{~km}$ north of IODP Site C0020.

dicate that a large-scale slump scar structure (escarpment) developed along the shelf break westward offshore from Cape Erimo and debris flow lobes and fragmented slump blocks widely distributed in the downstream part of the shelf break slump scar (Fig. 2).

The shallowest sedimentary sequence $(\sim 100 \mathrm{~m}$ b.s.f. $)$ at the drilling site primarily consists of a Quaternary sedimentary sequence including two MTDs (Upper and Middle MTDs in Fig. 3), overlying Pliocene units with a thicker MTD (Lower MTD in Fig. 3) (Takano, 2017; von Huene et al., 1980).

\section{Coring operation and analytical flow}

In the $4 \mathrm{~d}$ SCORE expedition, the Chikyu successfully drilled three holes using the hydraulic piston coring system (Table 1). Coring of the first hole, C9033A, reached $100 \mathrm{~m}$ b.s.f. and formation temperature measurements using the APCT-3 tool were attempted five times. Core samples from C9033A were used for shipboard sampling and analysis. Plug-sediment samples for cell count and headspace gas analysis were collected from the interiors of freshly cut section ends. After whole sections were scanned with X-CT and logged with MSCL-W, whole round core samples for geochemistry and microbiology were retrieved, and the remaining sections were split for shipboard observation and sampling. The other cored sections were used for physical property measurements such as moisture and density, thermal conductivity and penetration strength. Basic geochemistry of both interstitial water and gas components was obtained by the shipboard scientific party. For microbiology, whole round core samples were collected immediately after 


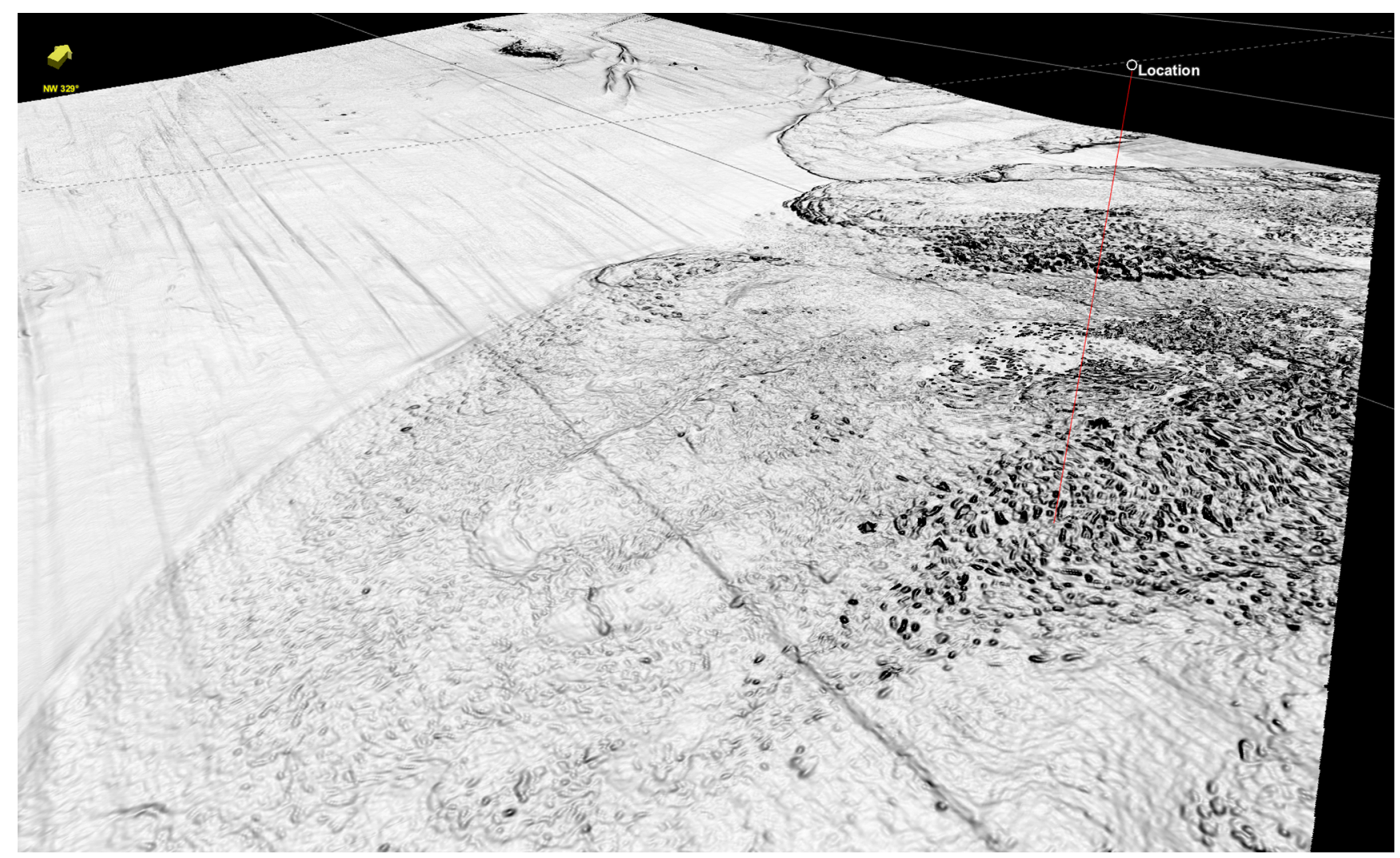

Figure 2. Three-dimensional view of topography around the drill site C9033. Rugged features indicate occurrences of mass transport. Seafloor topography detection from the seismic survey data (JOGMEC, 2013, 2014).

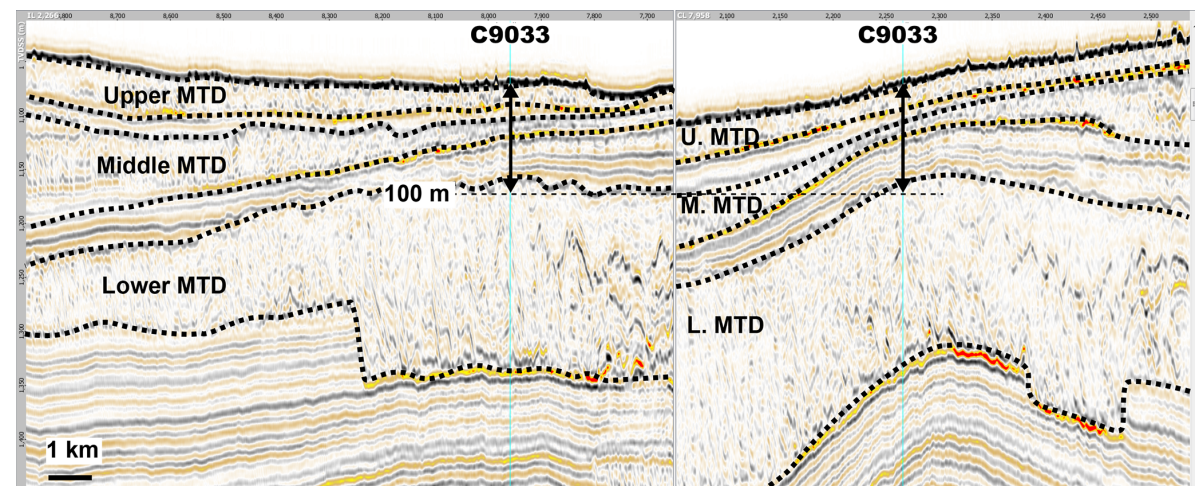

Figure 3. Seismic profiles at the drill site C9033 show transparent and/or chaotic intervals interpreted as mass transport deposits. There are three such intervals in the top $100 \mathrm{~m}$. Seismic profiles are from JOGMEC $(2013,2014)$.

$\mathrm{X}$-CT scan and processed for the appropriate storage prior to the post-cruise analysis (Morono and Inagaki, 2016).

Because of time constraints of the cruise, only one core from the seafloor was recovered from the second hole $\mathrm{C} 9033 \mathrm{~B}$, and the entire core was used for high-frequency sampling of interstitial water after X-CT observation (Fig. 4). The sections were then packed under the anaerobic condition (filled with $\mathrm{N}_{2}$ and vacuumed with oxygen-impermeable bags) for post-cruise use. From the third hole C9033C, 11 cores to $99.5 \mathrm{~m}$ b.s.f. were taken mainly for geological observations and post-cruise studies. The cores were split onboard after the non-destructive analysis and the split surface of archive halves was scanned for image archive. All sections were packed and stored at $+4{ }^{\circ} \mathrm{C}$ for shipping to Kochi Core Center, where all split sections were observed and described for lithostratigraphic study. 
Table 1. Hole and coring summary.

\begin{tabular}{lllrrrrr}
\hline Hole & Latitude & Longitude & $\begin{array}{r}\text { Water depth } \\
(\mathrm{m} \text { b.s.1. })\end{array}$ & $\begin{array}{r}\text { Cores } \\
(N)\end{array}$ & $\begin{array}{r}\text { Cored } \\
(\mathrm{m})\end{array}$ & $\begin{array}{r}\text { Recovered } \\
(\mathrm{m})\end{array}$ & $\begin{array}{r}\text { Recovery } \\
(\%)\end{array}$ \\
\hline $910-\mathrm{C} 0033 \mathrm{~A}$ & $41^{\circ} 48^{\prime} 08.33^{\prime \prime} \mathrm{N}$ & $142^{\circ} 21^{\prime} 27.88^{\prime \prime} \mathrm{E}$ & 1068.5 & 12 & 100.0 & 109.64 & 109.6 \\
$910-\mathrm{C} 0033 \mathrm{~B}$ & $41^{\circ} 48^{\prime} 08.33^{\prime \prime} \mathrm{N}$ & $142^{\circ} 21^{\prime} 27.88^{\prime \prime} \mathrm{E}$ & 1069.0 & 1 & 7.0 & 7.25 & 103.6 \\
$910-\mathrm{C} 0033 \mathrm{C}$ & $41^{\circ} 48^{\prime} 08.33^{\prime \prime} \mathrm{N}$ & $142^{\circ} 21^{\prime} 27.88^{\prime \prime} \mathrm{E}$ & 1069.0 & 11 & 99.5 & 107.47 & 108.0 \\
\hline
\end{tabular}

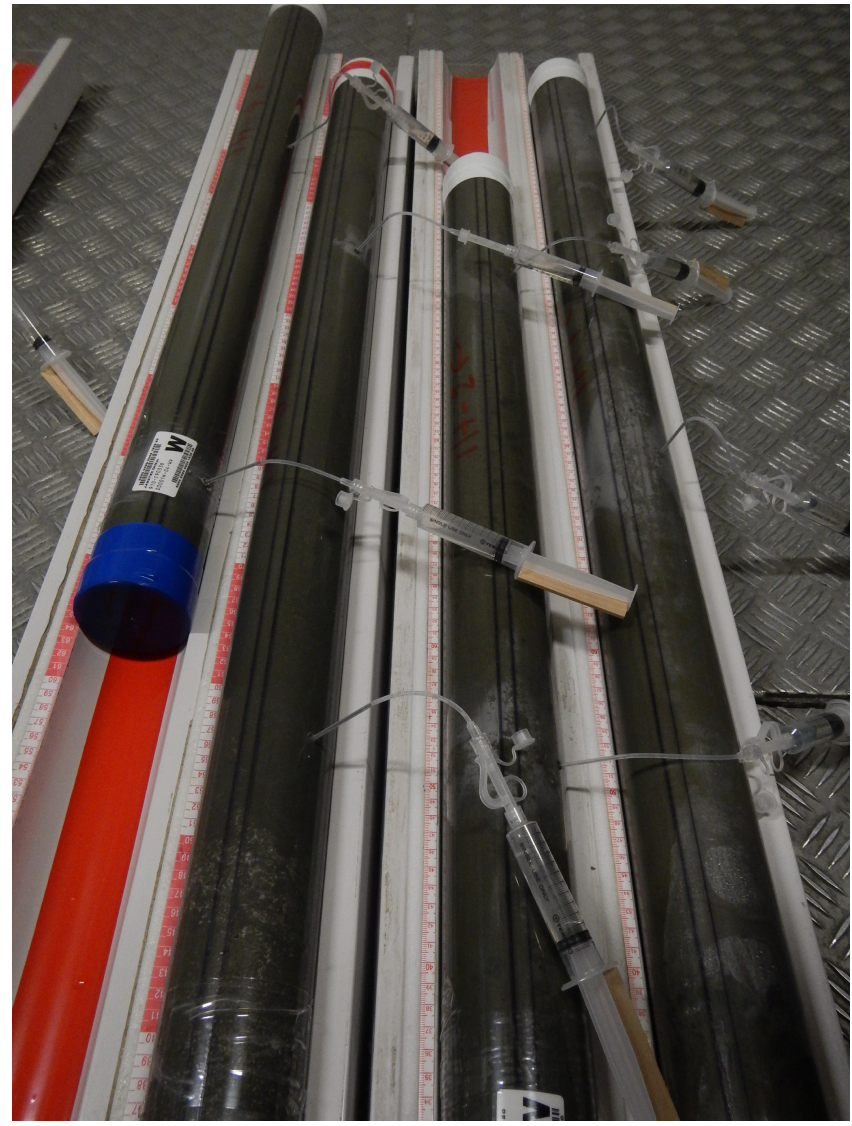

Figure 4. High-frequency pore water samples were taken from C9033B core sections using Rhizon samplers in a refrigerator room on the Chikyu.

\section{Preliminary results and discussion}

The main lithology of the cores was dark olive to olive grey silty clay with quartz, feldspar, volcanic glass, and microfossils of calcareous nannofossils, diatoms, and sponge spicules (Fig. 5). These massive sediments were unconsolidated, moderately bioturbated, and intercalated with sandy layers of various thicknesses commonly showing sharp bases and normal grading. There were several layers of volcaniclastic sediments, consisting of pumice, scoria, and volcanic glass (Fig. 5). The volcaniclastic sediments in the top $10 \mathrm{~m}$ b.s.f. contained coarse pumice, whereas tuffaceous sands were dominant in deeper intervals. Many of the volcaniclastic lay- ers showed inverse grading, and some thick layers were comprised of multiple units, each of which showed inverse or normal grading.

Four chaotic deposits characterized by scattered mud clasts and lack of stratification were observed in both Holes $A$ and C (Fig. 5). Neither normal nor inverse grading was observed in the chaotic deposits. Mud clasts were matrix supported without preferred orientation (Fig. 6). The mud clasts were predominantly silty clay, usually darker olive grey in colour than that of the surrounding matrix, with sub-rounded to sub-angular forms. The size of the clasts varied from centimetres to tens of centimetres in length.

The most distinct chaotic deposits were observed in 60.3$64.4 \mathrm{~m}$ b.s.f. in C9033A. A folded mud clast was found at C9033A-8H-10, $63 \mathrm{~cm}$ (Fig. 6). An overturned sand bed, which apparently showed a sharp top and inversed grading in appearance, was observed at C9033A-9H-4, $19 \mathrm{~cm}$ (Fig. 6). Another good example of chaotic bedding was found in $45.0-49.4 \mathrm{~m}$ b.s.f. in C9033C, which included a sandy turbidite at the top.

The chaotic deposits were accompanied by intervals showing inclined bedding. The bedding angle was mostly $5-15^{\circ}$, but was up to $40^{\circ}$ in some cases. Except for the inclination, the lithologies of the inclined bedding were similar to those of other hemipelagic sediments with horizontal laminae.

The combinations of inclined bedding and chaotic deposits are often reported from MTDs in other present deepwater basins (e.g. Algar et al., 2011; Alves, 2015) and exposed ancient MTDs (Ogata et al., 2012; Sola et al., 2018). Assuming the combination of the two features indicates MTD, there were three MTD units in both Holes A and C (Fig. 5). The first unit (46.0-56.6 m b.s.f. in 9033A and 45.0$56.1 \mathrm{~m}$ b.s.f. in $9033 \mathrm{C}$ ) is about $10 \mathrm{~m}$ thick and contains two chaotic deposits, which sandwich an interval of inclined bedding. The second unit $(60.3-69.0 \mathrm{~m}$ b.s.f. in $9033 \mathrm{~A}$ and $59.5-$ $69.0 \mathrm{~m}$ b.s.f. in $9033 \mathrm{C}$ ) consists of a chaotic deposit underlain by silty clay with inclined laminae. The third unit consists of the bottom $8 \mathrm{~m}$, continuing deeper, in 9033A and has thin chaotic deposits and silty clay with inclined bedding. The upper boundary of this unit at Hole $9033 \mathrm{C}$ is unclear due to flow-in material during coring. In addition to these three MTD units, inclined bedding was observed without chaotic deposits at the top of all three holes.

The observed MTD units in the core can be clearly correlated with those observed in the seismic profile (Fig. 3). The 


\section{Site C9033}

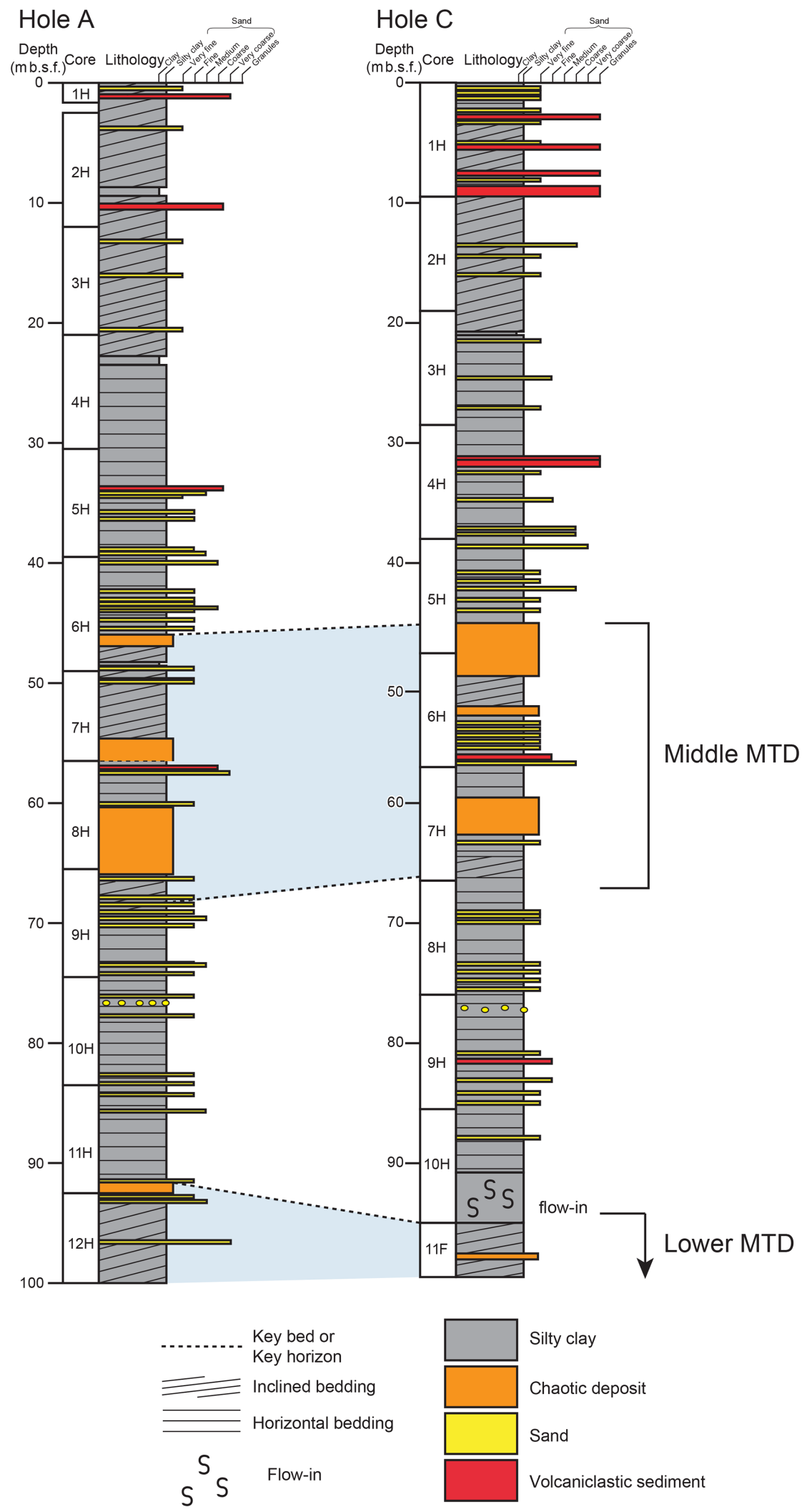

Figure 5. Lithologic column figure of Holes A and C at Site C9033. The combination of chaotic deposits and inclined beds is interpreted as mass transport deposits (MTDs). Two MTD units observed in the middle part of the core comprise "Middle MTD" in the seismic profile, whereas the MTD unit in the bottom corresponds to the top of "Lower MTD". Inclined bedding in the top 20 m may be another MTD layer. 

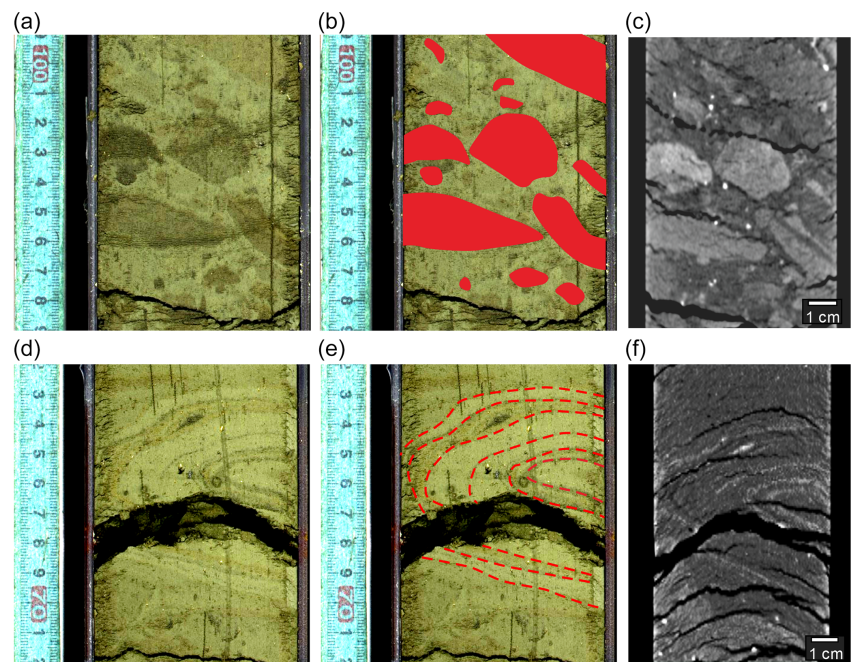

(e)
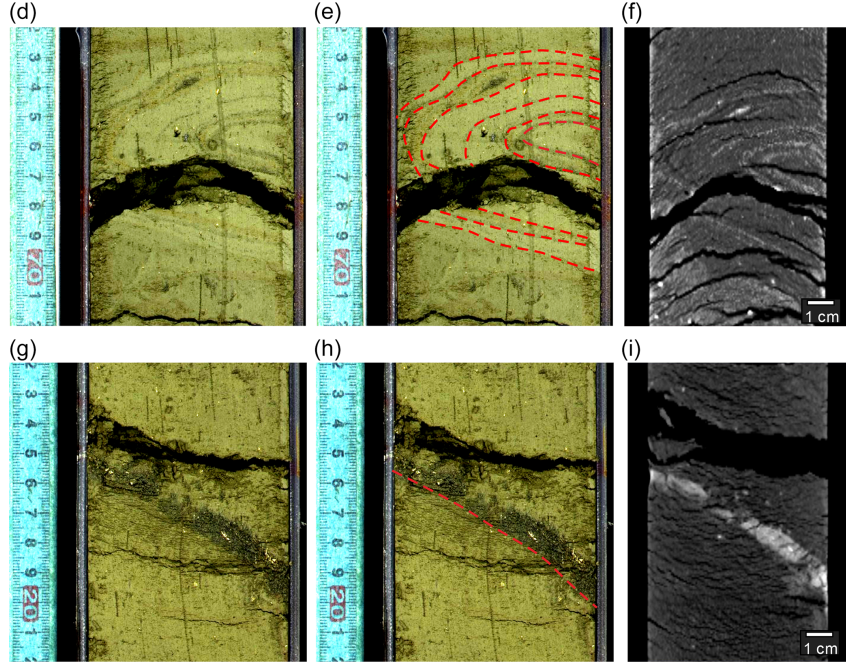

Figure 6. Three examples of deformation structures in the core samples: scattered mud clasts in C9033A-8H-6 (a, b, c), folded block in C9033A-8H-10 (d, e, f) and overturned bed with a sharp top and inverse grading in C9033A-9H-4 (g, h, i).

first and second MTD units comprise the Middle MTD in the seismic profile, whereas the third MTD corresponds to the top of the Lower MTD. Similarly, the inclined bedding at the top of all three holes may correspond to the Upper MTD of the seismic profile.

\section{Summary}

Chikyu's new coring programme, SCORE, provides the ocean drilling community with the opportunity to conduct short-term drilling expeditions for the drilling of shallow holes of up to $100 \mathrm{~m}$ b.s.f. With the simplified proposal review process, SCORE will open up possibilities for new research in a timely manner. The first SCORE expedition drilled three holes down to a maximum depth of $100 \mathrm{~m}$ b.s.f. off Cape Erimo, northern Japan. The sediment cores showed features such as chaotic deposits and inclined bedding, indicating repeated occurrences of mass transport deposits in the foreland basin. Post-cruise shore-based analyses will investigate the impact of such geological events on the local subseafloor microbial biosphere.
Data availability. The research data are available from http: //www.godac.jamstec.go.jp/catalog/doc_catalog/metadataDisp/ CK17-S01_910_all?lang=en (Kubo et al., 2020).

Team list. Yusuke Kubo (Center for Deep Earth Exploration, Japan Agency for Marine-Earth Science and Technology, Yokohama, Japan; Kochi Institute for Core Sample Research, Japan Agency for Marine-Earth Science and Technology, Kochi, Japan), Fumio Inagaki (Research and Development Center for Ocean Drilling Science, Japan Agency for Marine-Earth Science and Technology, Yokohama, Japan; Mantle Drilling Promotion Office (MDP), Institute for Marine-Earth Exploration and Engineering (MarE3), Japan Agency for Marine-Earth Science and Technology (JAMSTEC), Yokohama, Japan), Tatsuhiko Hoshino (Kochi Institute for Core Sample Research, Japan Agency for MarineEarth Science and Technology, Kochi, Japan), Akira Ijiri (Kochi Institute for Core Sample Research, Japan Agency for MarineEarth Science and Technology, Kochi, Japan), Hiroaki Kurano (Graduate school of frontier science, the University of Tokyo, Chiba, Japan), Yuki Morono (Kochi Institute for Core Sample Research, Japan Agency for Marine-Earth Science and Technology, Kochi, Japan), Yuichi Okuma (Atmosphere and Ocean Research Institute, the University of Tokyo, Chiba, Japan), Fumiaki Okumura (Japan Petroleum Exploration Co., Ltd (JAPEX), Chiba, Japan), Satoko Owari (School of Marine Resources and Environment, Tokyo University of Marine Science and Technology, Tokyo, Japan), Donald Pan (Japan Agency for Marine-Earth Science and Technology, Yokosuka, Japan), Wataru Tanikawa (Kochi Institute for Core Sample Research, Japan Agency for Marine-Earth Science and Technology, Kochi, Japan), Takeshi Terada (Marine Works Japan, Ltd., Yokosuka, Japan), Hitoshi Tomaru (Department of Earth Sciences, Graduate School of Science, Chiba University, Chiba, Japan), and Go-Ichiro Uramoto (Center for Advanced Marine Core Research, Kochi University, Kochi, Japan).

Author contributions. YK, FI and the Expedition 910 Shipboard Scientific Party led the conception and design of the manuscript. YK, ST, GIU, OT and YY conducted the core description and interpretation. YK and FI drafted the manuscript. All the authors edited the manuscript.

Competing interests. The authors declare that they have no conflict of interest.

Acknowledgements. We thank all crews, drilling team members, and technical staff on the Chikyu for support with core sampling during the first SCORE Expedition 910. We are grateful to $\mathrm{Fe}$ lix Beuling, Clemens Glombitza, Verena Heuer, Kai-Uwe Hinrichs, Victoria Orphan, and Tina Treude for useful discussions and shorebased collaborations. We also thank Nan Xiao for sample curation and storage of biological samples at Kochi Core Center. We are grateful for permission from the Ministry of Economics, Trade and Industry (METI) and JOGMEC for use of their seismic and bathymetric data. 
We thank Jan Behrmann for handling the editorial process and the two reviewers for submitting their helpful comments and improving the manuscript.

Financial support. This research has been supported by the Japan Society for the Promotion of Science (JSPS) Strategic Fund for Strengthening Leading-Edge Research and Development (to JAMSTEC and Fumio Inagaki), the JSPS Funding Program for Next Generation World-Leading Researchers (grant no. GR102 to Fumio Inagaki), the Grant-in-Aid for Science Research (grant no. 26251041 to Fumio Inagaki), and the Japan Petroleum Exploration Co. Ltd.

Review statement. This paper was edited by Jan Behrmann and reviewed by two anonymous referees.

\section{References}

Algar, S., Milton, C., Upshall, H., Roestenburg, J., and Crevello, P.: Mass-transport deposits of the deepwater Northwestern Borneo margin - Characterization from seismic-reflection, borehole, and core data with implications for hydrocarbon exploration and exploitation, SEPM Spec. P., 96, 351-366, https://doi.org/10.2110/sepmsp.096.351, 2011.

Alves, T. M.: Submarine slide blocks and associated soft-sediment deformation in deep-water basins: A review, Mar. Petrol. Geol., 67, 262-285, https://doi.org/10.1016/j.marpetgeo.2015.05.010, 2015.

Biddle, J. F., Lipp, J. S., Lever, M. A., Lloyd, K. G., Sørensen, K. B., Anderson, R., Fredricks, H. F., Elvert, M., Kelly, T. J., Schrag, D. P., Sogin, M. L., Brenchley, J. E., Teske, A., House, C. H., and Hinrichs, K.-U.: Heterotrophic Archaea dominate sedimentary subsurface ecosystems off Peru, P. Natl. Acad. Sci. USA, 103, 3846-3851, 2006.

D’Hondt, S., Jørgensen, B. B., Miller, D. J., Batzke, A., Blake, R., Cragg, B. A., Cypionka, H., Dickens, G. R., Ferdelman, T., Hinrichs, K.-U., Holm, N. G., Mitterer, R., Spivack, A., Wang, G., Bekins, B., Engelen, B., Ford, K., Gettemy, G., Rutherford, S. D., Sass, H., Skilbeck, C. G., Aiello, I. W., Guerin, G., House, C., Inagaki, F., Meister, P., Naehr, T., Niitsuma, S., Parkes, R. J., Schippers, A., Smith, D. C., Teske, A., Wiegel, J., Padilla, C. N., and Acosta, J. L. S.: Distributions of metabolic activities in deep subseafloor sediments, Science, 306, 2216-2200, 2004.

D'Hondt, S., Inagaki, F., Zarikian, C. A., Abrams, L. J., Dubois, N., Engelhardt, T., Evans, H., Ferdelman, T., Gribsholt, B., Harris, R. N., Hoppie, B. W., Hyun, J.-H., Kallmeyer, J., Kim. J., Lynch, J. E., McKinley, C. C., Mitsunobu, S., Morono, Y., Murray, R. W., Pockalny, R., Sauvage, J., Shimono, T., Shiraishi, F., Smith, D. C., Smith-Duque, C., Spivack, A. J., Steinsbu, B. O., Suzuki, Y., Szpak, M., Toffin, L., Uramoto, G., Yamaguchi, T. Y., Zhang, G., Zhang, X.-H., and Ziebis, W.: Presence of oxygen and aerobic communities from seafloor to basement in deep-sea sediment, Nat. Geosci., 8, 299-304, 2015.

Hoehler, T. M., and Jørgensen, B. B.: Microbial life under extreme energy limitation., Nat. Rev. Microbiol., 11, 83-94, 2013.
Inagaki, F., Suzuki, M., Takai, K., Oida, H., Sakamoto, T., Aoki, K., Nealson, K. H., and Horikoshi, K.: Microbial communities associated with geological horizons in coastal subseafloor sediments from the Sea of Okhotsk, Appl. Environ. Microbiol., 69, 7224-7235, 2003.

Inagaki, F., Nunoura, T., Nakagawa, S., Teske, A., Lever, M., Lauer, A., Suzuki, M., Takai, K., Delwiche, M., Colwell, F. S., Nealson, K. H., Horikoshi, K., D’Hondt, S., and Jørgensen, B. B.: Biogeographical distribution and diversity of microbes in methane hydrate-bearing deep marine sediments on the Pacific Ocean Margin, P. Natl. Acad. Sci. USA, 103, 2815-2820, 2006.

Inagaki, F., Hinrichs, K.-U., Kubo, Y., Bowles, M. W., Heuer, V. B., Hong, W.-L., Hoshino, T., Ijiri, A., Imachi, H., Ito, M., Kaneko, M., Lever, M. A., Lin, Y.-S., Methé, B. A., Morita, S., Morono, Y., Tanikawa, W., Bihan, M., Bowden, S. A., Elvert, M., Glombitza, C., Gross, D., Harrington, G. J., Hori, T., Li, K., Limmer, D., Liu, C.-H., Murayama, M., Ohkouchi, N., Ono, S., Park, Y.-S., Phillips, S. C., Prieto-Mollar, X., Purkey, M., Riedinger, N., Sanada, Y., Sauvage, J., Snyder, G., Susilawati, R., Takano, Y., Tasumi, E., Terada, T., Tomaru, H., Trembath-Reichert, E., Wang, D. T., and Yamada, Y.: Exploring deep microbial life down to $\sim 2.5 \mathrm{~km}$ below the ocean floor, Science, 349, 420-424, 2015.

Itoh, Y. and Tsuru, T.: Evolution history of the Hidaka-oki (offshore Hidaka) basin in the southern central Hokkaido, as revealed by seismic interpretation, and related tectonic events in an adjacent collision zone, Phys. Earth Planet. Int., 153, 220-226, 2005.

Japan Oil, Gas and Metal National Corporation (JOGMEC): National Program for Oil and Gas Prospecting, 2013 FY Geophysical Survey and Basin Evaluation Project "Hidaka Shujo Kaibon 3D”, Japan Oil, Gas and Metals National Corporation, Tokyo, Japan, 2013.

Japan Oil, Gas and Metal National Corporation (JOGMEC): National Program for Oil and Gas Prospecting, 2014 FY Geophysical Survey and Basin Evaluation Project "Hidaka Shujo KaibonSeibu 3D”, Japan Oil, Gas and Metals National Corporation, Tokyo, Japan, 2014.

Kallmeyer, J., Pockalny, R., Adhikari, R. R., Smith, D., and D'Hondt, S.: Global distribution of microbial abundance and biomass in subseafloor sediment, P. Natl. Acad. Sci. USA, 109, 16213-16216, 2012.

Kimura, G. and Kusunoki, K.: The Hidaka orogeny and tectonics of arc-arc junction, Mem. Geol. Soc. Japan, 47, 295-305, 1997.

Kubo, Y., Inagaki, F., and the Expedition 910 Shipboard Scientists: JAMSTEC Chikyu SCORE Expedition 910 "The west off Cape Erimo Drilling”, Preliminary Cruise Report, available at: http://www.godac.jamstec.go.jp/catalog/doc_ catalog/metadataDisp/CK17-S01_910_all?lang=en, last access: 19 February 2020.

Morono, Y. and Inagaki, F.: Analysis of low-biomass microbial communities in the deep biosphere, Adv. Appl. Microbiol., 95, 149-178, 2016.

Noda, A., Tuzino, T., Joshima, M., and Goto, S.: Mass transportdominated sedimentation in a foreland basin, the Hidaka Trough, norther Japan, Goechem. Geophy. Geosy., 14, 2638-2660, https://doi.org/10.1002/ggge.20169, 2013.

Ogata, K., Mutti, E., Pini, G. A., and Tinterri, R.: Mass transport-related stratal disruption within sedimentary mélanges: Examples from the northern Apennines (Italy) and south- 
central Pyrenees (Spain), Tectonophysics, 568-569, 185-199, https://doi.org/10.1016/j.tecto.2011.08.021, 2012.

Orsi, W. D., Edgcomb, V. P., Christman, G. D., and Biddle, J. F.: Gene expression in the deep biosphere, Nature, 499, 205-208, https://doi.org/10.1038/nature12230, 2013.

Seno, T., Sakurai, T., and Stein, S.: Can the Okhotsk plate be discriminated from the North American plate?, J. Geophys. Res.Sol. Ea., 101, 11305-11315, https://doi.org/10.1029/96JB00532, 1996.

Sola, F., Puga-Bernabéu, Á., Aguirre, J., and Braga, J. C.: Origin, evolution and sedimentary processes associated with a late Miocene submarine landslide, southeast Spain, Sediment. Geol., 364, 351-366, https://doi.org/10.1016/j.sedgeo.2017.09.005, 2018.

Takano, O.: Intermittent formation, sedimentation and deformation history of Cenozoic forearc basins along the northwestern Pacific margins as an indicator of tectonic scenarios, in: Dynamics of Arc Migration and Amalgamation Architectural Examples from the NW Pacific Margin, edited by: Itoh, Y., Takano, O., and Takashima, R., InTech, 1-24, https://doi.org/10.5772/intechopen.68290, 2017.
Tully, B. J. and Heidelberg, J.: Potential mechanisms for microbial energy acquisition in oxic deep-sea sediments, Appl. Environ. Microbiol., 82, 4232-4243, 2016.

Valentine, D. L.: Adaptations to energy stress dictate the ecology and evolution of the Archaea, Nat. Rev. Microbiol., 5, 316-323, 2007.

Von Huene, R., Langseth, M., Nasu, N., and Okada, H.: Summary, Japan Trench Transect, Initial Reports, DSDP, 57, 473488, 1980.

Yamada, Y., Kawamura, K., Ikehara, K., Ogawa, Y., Urgeles, R., Mosher, D., Chaytor, J., and Strasser, M. (Eds.): Submarine Mass Movements and Their Consequences, Advances in Natural and Technological Hazards Research Series, Springer, Dordrecht, the Netherlands, 1-769, 2012. 